is rather elosely proportional to the total amount of muscle tissue and independent of muscular activity. This may be explained if it is assumed that there is a spontaneous breakdown of phosphocreatine resulting in the formation of some creatinine. The phosphocreatine breakdown through specific activity yielding the energy-rich phosphate group to some acceptor can readily be imagined to give rise to no creatinine formation, thus explaining why the creatinine output is independent of muscular activity.

Another problem which may perhaps be attacked on the basis of the present observation is the active renal secretion of creatinine.

According to the hypothesis that a necessary condition of renal tubular secretion is that the substance is an acid ${ }^{1}$, creatinine should not be secreted; and it is in fact the only substance not found to obey this rule, at least in mammals.

Rehberg ${ }^{2}$ has suggested that phosphocreatine, known to occur in plasma after the injection of creatinine $^{3}$, may be converted into creatinine in the tubular cells and thus be responsible for part of the urinary creatinine. This suggestion seems to find support in the observation that phosphocreatine may form creatinine spontaneously. The tubular cells are supposed to exhibit a strong non-specific phosphatase activity, thus making possible a partial conversion of phosphocreatine into creatinine. That phosphocreatine should be absorbed from the blood stream by the tubular cells is well in accord with the hypothesis mentioned ${ }^{1}$.

Institute of Legal Medicine,

University of Copenhagen. Dec. 3.

${ }^{1}$ Lundquist, F., Acta Pharm. et Tox., 1, 307 (1945).

Rehberg, P. B., XVI Int. Physiol. Kongress, Kongressber., 1, 4 (1938).

'Abdon, N-O., Kungl. Fysiograf. Sälsk. i Lund Förhandl., 5, 14 (1935).

\section{Preparation of Cell-free Tryptophanase}

IN our earliest studies on the tryptophanase complex ${ }^{1}$ active non-viable suspensions of $E$. coli were used. These had been sterilized by shaking with chloroform, 1 volume to 2 volumes of suspension. The mixture was shaken vigorously to 200 r.p.m. for 4 hours.

An active dry enzyme preparation was also prepared by precipitation of the cells with 66 per cent alcohol $\left(\right.$ at $0^{\circ}$ ) and subsequent washing with ice-cold absolute alcohol. Since at that time we were mainly concerned with the mechanism of the reaction, further work was not attempted; though occasional studies on the supernatants from viable cells suggested that the enzyme complex could be obtained as a cell-free preparation. More recently we have been concerned to know more of the nature of the enzyme complex, and the following represents the preparation of such a cell-free preparation and which, moreover, can be divided into a dialysable and nondialysable portion.

Cells grown for 22 hours at $37^{\circ}$ on a tryptic digest of cæsin solidified with agar were harvested, washed and filtered through glass wool. Thick creamy suspensions thus obtained were cooled in ice and poured into five volumes of ice-cold acetone with constant stirring. The flocculated cells were allowed to settle and then filtered off with gentle suction on a Buchner funnel, washed successively with acetone, acetone and ether, and finally ether, and dried in a desiccator.
Tests were made with buffer solutions of $p H 5,7$ and 9 to extract the enzyme from the powder. After overnight extraction, the suspensions were centrifuged and supernatants adjusted to $p \mathrm{H} 7 \cdot 4$. Activity of extraction was nil at $p \mathrm{H} 5$, faint at 7 and more marked at 9 .

The present technique employed is overnight extraction with borate buffer $p H \quad 8.6$ using $20 \mathrm{mgm}$. acetone-dried powder per ml. buffer. Whereas the optimum $p \mathrm{H}$ for the reaction by the intact organism is $7 \cdot 6$, the cell-free enzyme has an optimal $p \mathrm{H}$ range of $8-8 \cdot 5$. The activity obtained from such cell-free extracts has been, at the maximum, approximately 25 per cent of that obtained from intact organisms, presumably due to destruction of some portion(s) of the tryptophanase complex by acetone drying.

Dialysis of the cell-free extract has been performed, and both dialysate and protein portion have been shown to be inactive by themselves. When added to one another activity was regained.

Work is now in hand on the elucidation of the various factors of the enzyme complex, and a full report will be published at a later date.
E. A. Dawes
J. Dawson
F. C. HAPPOLD

Department of Biochemistry, School of Medicine, Leeds, 2.

Dec. 4.

${ }^{1}$ Biochem. J., 29, 1918 (1935).

\section{Yeast and Rickets}

In his address to the Seventh Congress of Biological Chemistry in Liège on October $3-6,1946$, Dr. H. D. Kay summarized some experiments on feeding pigs with yeast, carried out during the War at the National Institute for Research in Dairying in Reading. It was found that when the total food ration contained 8 per cent dried yeast, some of the animals developed stiffness and lameness, and were finally unable to stand. If the diet contained 20 per cent yeast, this condition developed rather papidly in all pigs. X-ray examination of the bones indicated that the pigs were, in fact, suffering from rickets. The rachitic symptoms could be prevented by a sufficient supply of vitamin $\mathrm{D}$, and could be almost completely prevented by increasing the calcium carbonate content of the diet from 1.5 to 4 per cent. When the yeast phosphorus was replaced by the corresponding amount of sodium phosphate phosphorus, no symptoms were produced.

During a recent visit to England, I discussed this problem with the Reading workers, who were now of the opinion that the rachitogenic effect of yeast might be connected with the high phytic acid content in the diet. The results of our experiments, which show that dried yeast is a strong inhibitor of the enzyme phytase, support this hypothesis.

The experiments were made on a crude enzyme solution extracted from rye bran. $25 \mathrm{ml}$. of the solution correspond to the phytase activity of about $15 \mathrm{gm}$. barley. The yeast used was dried brewers' top-yeast. The system contained $25 \mathrm{ml}$. enzyme solution and $72.0 \mathrm{mgm}$. phytate phosphorus, as pure sodium phytate; concentration of acetate buffer, $0.2 \mathrm{M}$.; total volume, $100 \mathrm{ml}$; $p H, 5 \cdot 20 \pm 0.05$; temp. $30^{\circ} \pm 0 \cdot 1^{\circ} \mathrm{C}$.; time of reaction $2 \mathrm{hr}$., at the end of which $10 \mathrm{ml}$. was taken out to control the $p H$ 